\title{
Abundance and size variation of Globorotalia menardii in the northeastern Indian Ocean during the late Quaternary
}

Swati Bhonsale and Rajeev Saraswat*

Micropaleontology Laboratory, National Institute of Oceanography, Dona Paula- 403 004, Goa, India

(*For correspondence: rsaraswat@nio.org)

\begin{abstract}
Variation in absolute abundance, size and coiling direction ratio of the planktic foraminifera Globorotalia menardii during the late Quaternary have been studied in three cores, collected along a north-south transect from the northeastern Indian Ocean. Increased abundance and larger size is observed during the warm interglacial period, whereas smaller and fewer G. menardii specimens are noted during the cold glacial periods. A comparatively better match between absolute abundance, size and oxygen isotopic composition of foraminifera as compared to carbon isotopic composition at all the locations indicates that the abundance and size of G. menardii is more affected by seawater temperature and salinity as compared to productivity changes. The amplitude and frequency of temporal changes in the abundance and size of G. menardii vary from core-to-core, indicating the influence of site-specific physico-chemical conditions. In comparison to the abundance and size, the coiling direction of G. menardii does not show any systematic change in any of the cores. The majority of the specimens coil sinistrally. We conclude that the absolute abundance and variation in average size of $G$. menardii can be used to infer past climatic changes. However, the variation in coiling direction of G. menardii appears to be unaffected by late Quaternary paleoclimatic variations in the north-eastern Indian Ocean.
\end{abstract}

Key words: Globorotalia menardii, abundance, size, coiling direction, northeastern Indian Ocean, temperature, salinity, productivity. 


\section{Introduction}

Morphological parameters including the average size of the test, and coiling direction of trochospirally coiled species of both benthic and planktic foraminifera, have often been used as paleoclimatic proxies. Though, the overall size of planktic foraminifera indicates an apparent phyletic trend, a detailed analysis shows that extinction events (Arnold et al., 1995), global cooling, productivity and other paleoceanographic changes have an influence on the size of different species (Hecht, 1976a; 1976b; Malmgren and Kennett, 1978a; 1978b; 1981; Nigam, 1990; 1996; Naidu and Malmgren, 1995; Huber et al., 2000; Renaud and Schmidt, 2003; Schmidt et al., 2004a; 2004b). However, the relationship between the morphological parameter of individual planktic foraminiferal species and the physico-chemical characteristics of the seawater vary from ocean to ocean because of different local adaptations in different bioprovinces (Bolli, 1971; Bé et al., 1973; Malmgren and Healy-Williams, 1973; Malmgren and Kennett, 1978a).

Of various planktic foraminifera, the coiling direction of Globorotalids has often been applied to the stratigraphic correlation of deep sea cores (Ericson and Wollin, 1956a; Nagappa, 1957). One of the earliest investigations on the variations in the coiling direction of Globorotalids was carried out by Bolli (1950). Among Globorotalid species, information about the factors controlling the coiling of Globorotalia menardii (Parker, Jones and Brady, 1865) is comparatively limited, especially from the Indian Ocean region. G. menardii is a tropical-subtropical species that lives preferentially in sub-surface waters below $50 \mathrm{~m}$ and probably descends to bathypelagic depths in late ontogeny (Bé and Tolderlund, 1971; Bé and Hutson, 1978). Previously, changes in morphology (shape and size) of G. menardii have been noted in response to changing water mass characteristics (Knappertsbusch, 2007; Regenberg et al., 2010). However, this response varies from ocean to ocean (Bolli, 1971; Knappertsbusch, 2007). Studies on G. menardii from other world oceans show that the abundance of differently coiled specimens during the same time interval varies from ocean to ocean. While several dextral-sinistral coiling fluctuations were noted in G. menardii populations during the middle to upper Miocene transition in the Caribbean region, only a single sinistral to dextral change marks the same boundary in the tropical Pacific region (Bolli, 1971). While summarising the coiling trends in planktic foraminifers, Bolli (1971) placed G. menardii under the category of species that show frequent changes in the preferred coiling direction. He further opined that these frequent fluctuations can be in response to changing seawater characteristics.

Additionally, the abundance of G. menardii shows a distinct glacial-interglacial trend with increased abundance during warmer periods (Schott, 1935; Ericson and Wollin 1956a; 1956b; 1968). Good correlation was noted between the frequency of G. menardii and oxygen isotopic ratio (Ericson 
and Wollin, 1956a). However, deviation was noted at a few intervals. In addition, the size of a few other species was also found to vary with seawater temperature in the Indian Ocean (Malmgren and Kennett, 1976). The size of Globorotalia menardii was reported to vary latitudinally in the western Atlantic (Cushman and Harris, 1927). Later, an increase in the size of G. menardii was noted from the Miocene till late Pleistocene (Knappertsbusch, 2007). However, such studies are limited. No attempt has yet been made to understand the change in the size of G. menardii, if any, during the last glacial-interglacial period in the Indian Ocean, and the factors responsible for it. The north-eastern Indian Ocean with huge freshwater influx and seasonally changing physico-chemical properties is a good location to study factors affecting the size of G. menardii.

Here we examine the paleoclimatic significance, if any, of the abundance and morphologic variations, including average size and the coiling direction of the trochospirally coiled planktic foraminifera Globorotalia menardii from the northeastern Indian Ocean. This study does not make any distinction between the different subspecies and morphotypes of $G$. menardii but excludes $G$. tumida and G. cultrata (Plate 1) because recently it was reported that these species have different ecological preferences (Regenberg et al., 2010). The morphological parameters of G. menardii are compared with the oxygen and carbon isotopic ratios, two well established paleoclimatic proxies. The aim of comparing the abundance and morphological characteristics of G. menardii with the stable oxygen and carbon isotopic compositions of foraminifera is to understand the relationship between climatic parameters and the change in its abundance and morphology over a well-known interval such as the last glacial to interglacial transition.

\section{Oceanographic Setting}

The northeastern Indian Ocean was selected as the study area (Fig. 1), as large seasonal and regional changes are noted in physico-chemical parameters in this region because of the monsoon and freshwater input by adjacent large rivers. Such large scale changes in seawater properties, especially over glacial-interglacial transitions, are expected to influence the morphology and abundance of planktic foraminifera. Dry north-easterly winds along with winter cooling and evaporation, as well as precipitation, heating and freshwater discharge during the southwest monsoon season has a pronounced effect on the surface circulation in the northeastern Indian Ocean (Schott and McCreary, 2001; Shankar et al., 2002). The surface circulation in the western part $\left(12^{\circ} \mathrm{N}\right.$ to $\left.16^{\circ} \mathrm{N}\right)$ of the northeastern Indian Ocean, varies from a strong cyclonic gyre from autumn through winter, replaced by an anti-cyclonic gyre during spring. A basin-wide anti-cyclonic gyre, with the East India Coastal Current (EICC) as its western boundary forms in the Bay of Bengal from February to May, and 
disappears during the summer monsoon (Schott and McCreary, 2001). During the winter season, the Bay of Bengal is characterized by a large cyclonic gyre. The surface circulation responds to all phases of El-Nino Southern Oscillation (ENSO) on an inter-annual scale (Somayajulu et al., 2003). The study area receives huge quantities of fresh water from the rivers in the adjoining regions and the effect of this fresh water discharge on the salinity structure of the study area is very pronounced. The annual average sea surface salinity (SSS) clearly shows the effect of fresh water discharge on the salinity in the study area, with salinity increasing from north to south. The sea surface temperature (SST) shows a significant spatio-temporal variation. The annual SST shows a roughly north-south increasing trend with the highest annual SST $\left(\sim 29^{\circ} \mathrm{C}\right)$ reported from both the eastern and western margins of the southern part of the study area. The northern part remains comparatively cooler $\left(\sim 27^{\circ} \mathrm{C}\right)$. However, the central part is warmer. The southeastern part of the study area is the warmest region of the Indian Ocean and it forms a part of the Indo-Pacific Warm Pool. This region has SSTs greater than $28^{\circ} \mathrm{C}$ throughout the year. The annual SST cycle for a location $\left(17.5^{\circ} \mathrm{N}, 88.5^{\circ} \mathrm{E}\right)$ in the central Bay of Bengal showed a rapid temperature rise during the pre-monsoon season, a long steady phase, with SST centred near $\sim 29^{\circ} \mathrm{C}$, followed by a sharp decline at the beginning of the winter monsoon season (Vinayachandran and Shetye, 1991).

In the northern part (north of $15^{\circ} \mathrm{N}$ ), the mixed layer depth (MLD) (the depth at which the density differs by $0.2 \mathrm{~kg} / \mathrm{m}^{3}$ of its surface value) is comparatively shallower $(\sim 20 \mathrm{~m})$ and persistent throughout the year, probably under the influence of fresh water. However deeper and strongly seasonal MLD (deeper during summer and winter monsoons while shallower during intermonsoon periods) is reported for the southern (south of $15^{\circ} \mathrm{N}$ ) part of the study area (Madhupratap et al., 2003; Narvekar and PrasannaKumar, 2006).

\section{Materials and Methodology}

Three gravity cores collected along a north- south transect in the Indian Ocean during the ORV Sagar Kanya and AA Sidorencko cruises, as part of the Ministry of Earth Sciences (formerly Department of Ocean Development) funded projects "Benthic foraminiferal studies in the subsurface samples of Bay of Bengal to reconstruct palaeoceanographic changes" and "Cobalt-Crust" were studied (Fig. 1, Table 1). A total of 179 samples from these three cores were chosen. All the cores were sub-sampled at $2 \mathrm{~cm}$ interval. These cores were selected as they lie in zones of distinctly different seawater properties. The salinity and productivity at the northernmost core (SK157/20) is influenced by freshwater influx from the rivers, whereas the southernmost core (CC1GC2) is mainly affected by equatorial processes. 
An appropriate amount (5-10 g) of sediment from each sub-sample was oven dried at $50^{\circ} \mathrm{C}$. The dried sample was weighed and soaked in water for 24 hours. Subsequently, sediments were wet sieved through a $63 \mu \mathrm{m}$ sieve. The size fraction $>63 \mu \mathrm{m}$ was weighed and transferred to plastic vials. The $>63 \mu \mathrm{m}$ fraction was taken and split into aliquots of $1 / 4$ for picking. A total of 8840 specimens of G. menardii were handpicked, giving an average of about 50 specimens per sample. The coiling direction and size was measured for all 8840 specimens using an Olympus Stereozoom microscope 'SZX12'. The size of the specimens was measured in spiral view using a digital camera connected to a computer via ACT 2U (Auto Camera Tame to you / utility) software (Fig. 2). In order to smoothen the data and to highlight the major changes, a five point moving average was carried out for both abundance and size of G. menardii.

Stable isotopic (oxygen and carbon) analysis was carried out on planktic foraminifera. For isotopic analyses, fifteen-twenty clean specimens of Globigerinoides ruber (white) from 250-355 $\mu \mathrm{m}$ size range were transferred to glass vials. However, for core $\mathrm{CC} 1 \mathrm{GC}$, the isotopic analyses were carried out on Pulleniatina obliquiloculata, since sufficient G. ruber specimens were not available. The stable isotopic analyses were performed at the Alfred Wegener Institute for Polar and Marine Research (Bremerhaven) using a "Finnigan MAT 251 isotope ratio gas mass spectrometer" coupled to an automated carbonate preparation device (Kiel I) and calibrated via NBS 19 to the PDB scale. The values are given in $\delta$-notation versus VPDB (Vienna Pee Dee Belemnite). Precision of oxygen and carbon isotope measurements based on repeat analyses of a laboratory standard over a one year period was better than $0.06 \%$ and $0.09 \%$ for carbon and oxygen, respectively. In view of large scale fluctuations in the stable carbon isotopic ratio, a three point moving average was calculated and plotted.

\section{Chronology}

The chronology for the sediment cores was established based on monospecific (Globigerinoides ruber or Globorotalia menardii) accelerator mass spectrometry (AMS) radiocarbon dates (Table 2) and tuning of the oxygen isotopic ratio to a low latitude isostack (Fig. 3). The radiocarbon dates for the upper portion of the cores were obtained from Leibniz Labor für Altersbestimmung und Isotopenforschung, Christian-Albrechts-Universität, Kiel. The radiocarbon dates were calibrated using CalPal version quickcal2005 ver.1.4 (Weninger and Joeris, 2006). The radiocarbon dates were corrected for reservoir effect (400 yr) before calibration. The chronology was extended down the core by tuning the oxygen isotopic ratios of planktic foraminifera to the low-latitude oxygen isotopic 
stack of Bassinot et al (1994). The core CC1GC2 covers a time span of $~ 98 \mathrm{kyr}$ with an average sample resolution of $\sim 1.2 \mathrm{kyr}$ (varying from $0.2 \mathrm{kyr}$ to $2.2 \mathrm{kyr}$ ), whereas core SK157/12 covers the last $\sim 65 \mathrm{kyr}$, at an average sample resolution of $\sim 1.2 \mathrm{kyr}$ (varying from 0.6 to $2.2 \mathrm{kyr}$ ). The northernmost core in the transect has the highest sedimentation rate. It covers a time span of $\sim 28 \mathrm{kyr}$, at an average sample resolution of $0.5 \mathrm{kyr}$.

\section{Results}

\section{Absolute Abundance of G. menardii}

The G. menardii abundance shows large variation (no specimen at several intervals in core SK 157/20 to a maximum of 3099 specimens/g dry sediment in southernmost core CC1GC2) (Fig. 4). Absolute abundance of $G$. menardii specimens increases from north to south with maximum abundance in the southernmost core $\mathrm{CC} 1 \mathrm{GC} 2$. In general a five-fold increase is noted in the $G$. menardii abundance from north to south. Globorotalia menardii abundance is higher during the Holocene in all three cores, as compared to that during the part of the last glacial period covered by the cores. However, a distinct difference in abundance at a glacial-interglacial scale is noted only in the northernmost core (SK 157/20). Here G. menardii abundance increases from the early Holocene onwards and reaches its peak during the mid-Holocene. As compared to the Holocene, G. menardii in core SK 157/20 are almost absent during the part of the last glacial period covered in the core.

In contrast to the northernmost core (SK157/20), the highest G. menardii abundance in both SK157/12 and CC1 GC2 cores, is noted between 20 kyr BP and 10 kyr BP. In both these cores, the G. menardii abundance is very low prior to $\sim 20 \mathrm{kyr}$ BP. The lowest G. menardii abundance (332/g sediment) in core SK157/12 is noted at $36 \mathrm{kyr}$ BP. In core CC1 GC2, the lowest abundance (348/g sediment) is reported at $\sim 68 \mathrm{kyr} \mathrm{BP}$. In this core, G. menardii abundance is very low from the bottom of the core till $\sim 60 \mathrm{kyr}$ BP. Large variations are noted in the abundance of G. menardii in cores SK 157/20 and CC1GC2 as compared to core SK 157/12. Though the lowest G. menardii abundance is nearly the same in both SK157/12 and CC1GC2, the highest abundance in CC1GC2 ( $\sim 3100 / \mathrm{g}$ sediment, at $\sim 17 \mathrm{kyr}$ BP) is more than twice that in SK157/12 (1211/g sediment).

\section{Average size of $G$. menardii}

As observed in the case of absolute abundance, the average size of G. menardii also varies over a glacial-interglacial time scale with increased size during the Holocene as compared to the last glacial period (Fig. 5). However, in contrast to the north to south increasing trend in abundance, the average size of G. menardii is relatively large in the northernmost core SK 157/20. The glacial-interglacial 
change in G. menardii average size is also the largest in core SK 157/20 as compared to the cores further south. Globorotalia menardii attains maximum size $(1043 \mu \mathrm{m})$ during the early Holocene in core SK $157 / 20$, whereas the lowest size $(458 \mu \mathrm{m})$ is also reported in the same core during the last glacial period.

\section{Coiling direction of $G$. menardii}

The majority of G. menardii specimens in all three cores are sinistrally coiled (Fig. 6). The percentage of specimens which are dextrally coiled is statistically insignificant (less than 10\%) at almost all the intervals, except a few, in all the cores. While the maximum percentage $(\sim 12 \%)$ of dextrally coiled specimens is noted in the northernmost core SK 157/20, the other two cores (SK $157 / 12$ and CC1GC2) have a comparable number of dextrally coiled specimens. The variation in the number of dextrally coiled specimens does not show any systematic change over glacial-interglacial periods in any of the cores. No inter-core correspondence is noted in the percentage of dextrally coiled specimens. In both SK 157/12 and CC1GC2 cores, the number of dextrally coiled specimens is zero at many intervals, i.e. all the specimens are sinistrally coiled.

\section{Abundance and size of $G$. menardii versus stable isotopic ratios}

The temporal variation in abundance of $G$. menardii shows a close correspondence $(\mathrm{R}=0.8)$ with the stable oxygen isotopic composition of foraminifera $\left(\delta^{18} \mathrm{O}_{\mathrm{f}}\right)$ in the northernmost core (SK157/20) (Fig. 7). However, the correlation between G. menardii abundance and $\delta^{18} \mathrm{O}_{\mathrm{f}}$ varies latitudinally and decreases in both SK157/12 and CC1GC2 cores. Globorotalia menardii abundance and $\delta^{18} \mathrm{O}_{\mathrm{f}}$ are poorly correlated $(\mathrm{R}=0.3)$ in core $\mathrm{CC} 1 \mathrm{GC} 2$. The correlation between $G$. menardii abundance and $\delta^{13} \mathrm{C}_{\mathrm{f}}$ also decreases from north to south, being highest $(\mathrm{R}=0.5)$ in core SK157/20, while lowest $(\mathrm{R}$ $=0.03$ ) in core $\mathrm{CC} 1 \mathrm{GC} 2$. The changes in G. menardii abundance are comparatively well correlated with $\delta^{18} \mathrm{O}_{\mathrm{f}}$, than to $\delta^{13} \mathrm{C}_{\mathrm{f}}$.

Like G. menardii abundance, its average size also shows a latitudinally varying relationship with both $\delta^{18} \mathrm{O}_{\mathrm{f}}$ and $\delta^{13} \mathrm{C}_{\mathrm{f}}$ (Fig. 8). The average size of $G$. menardii is well correlated $(\mathrm{R}=0.7)$ with $\delta^{18} \mathrm{O}_{\mathrm{f}}$ in the northernmost core (SK157/20) and poorly correlated $(\mathrm{R}=0.3)$ in the rest of the cores. The least correlation is noted between G. menardii size and $\delta^{13} \mathrm{C}_{\mathrm{f}}$ in all three cores (Fig. 8).

In general, depleted $\delta^{18} \mathrm{O}_{\mathrm{f}}$ coincides with the increased abundance of G. menardii. A similar relationship is also noted between the average size of $G$. menardii and $\delta^{18} \mathrm{O}_{\mathrm{f}}$, with a comparatively larger average size corresponding to depleted $\delta^{18} \mathrm{O}_{\mathrm{f}}$. Though the $\delta^{13} \mathrm{C}_{\mathrm{f}}$ also shows an apparent relationship with variations in average size and abundance, the relationship differs at certain 
intervals. Like, in core SK $157 / 20$, the increase in $\delta^{13} \mathrm{C}_{\mathrm{f}}$ during $20 \mathrm{Kyr}$ BP to $10 \mathrm{Kyr}$ BP does not have a corresponding proportional increase in either abundance or average size. However, in core SK $157 / 12$, a marginally better correspondence is noted between $G$. menardii abundance and $\delta^{13} C_{\mathrm{f}}$ at several intervals (Fig. 6). In this core, a similar close correspondence is also noted between $\delta^{13} \mathrm{C}_{\mathrm{f}}$ and average size of G. menardii. Unlike cores SK 157/12 and SK 157/20, no evident relationship is observed between $\delta^{13} \mathrm{C}_{\mathrm{f}}$ and abundance or average size of G. menardii in core CC1GC2 (Fig. 8). In general, enriched $\delta^{13} \mathrm{C}_{\mathrm{f}}$ coincides with an increase in the average size of $G$. menardii.

\section{Discussion}

A five times increase in absolute abundance of G. menardii from north to south, indicates the influence of varying temperature, salinity and productivity. Cullen and Prell (1984) also noted a southward increase in abundance of G. menardii in the Bay of Bengal. Both, seawater salinity and temperature increase from north to south, with the northernmost core being located in relatively cool and less saline waters. G. menardii is a warm water species and its temporal variation combined with a few other warm water planktic foraminiferal species has often been used to infer past temperature changes (Kennett and Huddlestun, 1972; Balsam and Flessa, 1978; Naidu, 1991; Huang et al., 2003). The seawater at the southernmost core $(\mathrm{CC} 1 \mathrm{GC} 2)$ site is the warmest, thus leading to the highest abundance of G. menardii in this core. Part of the differences in the abundance of G. menardii in the three cores can arise due to change in the foraminiferal lysocline depth, which is relatively shallower in the central Bay of Bengal $\left(\sim 3,000 \mathrm{~m}\right.$ at $\left.15^{\circ} \mathrm{N}\right)$ as compared to the eastern equatorial region $(>4600$ m) (Cullen and Prell, 1984). The shallow lysocline will lead to comparatively more dissolution of planktic foraminifera including G. menardii, thus resulting in its low abundance in the northern core (SK157/20).

Additionally, the decreased productivity around the northern core, due to reduced nutrient input as a result of freshwater influx induced vertical stratification (PrasannaKumar et al., 2002; Madhupratap et al., 2003), might also be responsible for the lower abundance of G. menardii in the northernmost core SK 157/20. Such monsoon induced seasonality in both biogenic and terrigenous fluxex in the northern Bay of Bengal was also noted by Unger et al (2003), based on sediment trap studies. Globorotalia menardii abundance prior to $\sim 20 \mathrm{kyr}$ BP is low in all three cores, as compared to the last glacial-interglacial transition and the Holocene, which again indicates that it is a warm water species and its abundance decreases during cold glacial periods. Ericson and Wollin (1968) also noted an increase in the abundance of $G$. menardii during interglacial periods, in a number of cores collected from the Atlantic Ocean. Similarly, Sarkar and Guha (1997) also noted increased G. 
menardii abundance during interglacial periods in Pleistocene samples from the northwestern Indian Ocean.

The distinct difference in abundance at the glacial-interglacial scale, with near absence during the last glacial period, only in the northernmost core (SK 157/20), indicates that the seawater properties at this core site are at the lower tolerance limit of G. menardii. Any further drop in seawater temperature/salinity, etc during the glacial period would lead to a drastic decrease in abundance of $G$. menardii as it could not survive under those conditions. This north to south difference in G. menardii abundance during glacial-interglacial periods can also be attributed to the changes in seawater temperature and salinity gradients in the Bay of Bengal. The difference in $\delta^{18} \mathrm{O}$ between last glacial maximum and Holocene was the largest in the northern Bay of Bengal and decreased towards the equator (Duplessy, 1982). It indicates that large variation in seawater temperature and salinity occurred in the northern region as compared to the southern Bay of Bengal, which lead to disparity in the response of G. menardii abundance during glacial-interglacial periods in the three cores.

Although there are many factors affecting the size of marine microorganisms (Schmidt et al., 2006), the large variation in average size of G. menardii over glacial-interglacial periods in core SK $157 / 20$, probably arises due to the relatively large change in the seawater salinity and temperature in the northern part of the study area as compared to the southern part, over glacial-interglacial timescales (Duplessy, 1982). Large water-mass stratification changes in the northern part of the study area due to fresh water influx, might also have lead to a relatively large variation in the G. menardii size at this site. Schmidt et al (2004c) also attributed changes in the size of planktic foraminifera to the changes in the water mass stratification. Differences in the productivity in the northern and southern parts of the Bay of Bengal Fan (PrasannaKumar et al., 2002; Madhupratap et al., 2003) might also induce variation in the average size of $G$. menardii as noted in the cores. Water mass control on the morphology of planktic foraminiferal species has earlier been noted by several workers (Hecht, 1976a; Hecht et al., 1976; Williams, 1984; 1989). In the present study, though the difference is noted in the size of G. menardii over glacial-interglacial time periods, site specific physico-chemical characteristics of the seawater induce large difference in the temporal variation of G. menardii size at different locations. Thus the size of G. menardii in the north-eastern Indian Ocean can only be applied for correlation of cores, after considering the differences in physicochemical parameters at different locations.

The average size of G. menardii co-varies with the abundance and is comparatively higher during the interglacial period than the last glacial period. The increased abundance and average size 
of G. menardii during warmer intervals confirm the conclusions of Hecht (1976a), that the species attains optimum size and abundance during favourable conditions.

The temporal variation in abundance of $G$. menardii shows better correlation $(\mathrm{R}=0.8)$ with the stable oxygen isotopic composition of foraminifera $\left(\delta^{18} \mathrm{O}_{\mathrm{f}}\right)$ than with $\delta^{13} \mathrm{C}_{\mathrm{f}}(\mathrm{R}=0.5)$ in core SK157/20, which shows that the influence of seawater temperature and salinity on G. menardii abundance is large as compared to productivity. However, the $G$. menardii abundance and $\delta^{18} \mathrm{O}_{\mathrm{f}}(\mathrm{R}=$ $0.3)$ as well as $\delta^{13} \mathrm{C}_{\mathrm{f}}(\mathrm{R}=0.03)$ are poorly correlated in the southernmost core CC1GC2, which may be due to the small difference in seawater properties over glacial-interglacial periods.

Like $G$. menardii abundance, the average size of $G$. menardii is well correlated $(\mathrm{R}=0.7)$ with $\delta^{18} \mathrm{O}_{\mathrm{f}}$ than with $\delta^{13} \mathrm{C}_{\mathrm{f}}(\mathrm{R}=0.1)$ in the northernmost core $(\mathrm{SK} 157 / 20)$, which again shows that seawater temperature and salinity affects the size of $G$. menardii more than productivity. Though the correlation value varies from core to core, G. menardii size and $\delta^{13} \mathrm{C}_{\mathrm{f}}$ are less correlated as compared to $G$. menardii size and $\delta^{18} \mathrm{O}_{\mathrm{f}}$ in all three cores, which indicates that productivity has a smaller effect on G. menardii size than seawater temperature and salinity. The latitudinally varying relationship between average size and both $\delta^{18} \mathrm{O}_{\mathrm{f}}$ and $\delta^{13} \mathrm{C}_{\mathrm{f}}$ may also be attributed to the north-south difference in seawater properties over glacial-interglacial periods. High abundance and larger size of G. menardii correlates with depleted $\delta^{18} \mathrm{O}_{\mathrm{f}}$, indicating that it prefers warmer water.

The temporal abundance of dextral tests of G. menardii shows an insignificant variation during the last $\sim 100 \mathrm{kyr}$ BP. The peaks in down-core variation of dextrally coiled specimens are due to the rare presence of dextral specimens in a few samples, while the majority of the G. menardii specimens are sinistraly coiled. Similar observations were made by Bolli $(1950 ; 1951)$, although he noted a systematic variation in the coiling direction of many of the Globorotalids throughout the geologic past, with an equal number of dextral and sinistral specimens restricted to the older sequences, and with the stratigraphically younger horizons containing specimens coiled in only one direction. However, the latter trend was noted only in a few of the Goloborotalid species, whereas the others, including Globorotalia menardii were found to have a complex pattern of coiling through the geologic past (Bolli, 1950). Although, seasonal variation in physico-chemical factors including distance from the land and water depth have also been suggested to control the coiling pattern, the exact factors regulating the coiling direction could not be delineated (Bé, 1960; Thiede, 1971). Sierro (1985) and Sierro et al (1993) noted the potential application of variation in the coiling direction of the G. menardii group to recognize interactions between the Atlantic and Mediterranean realms. However, no such factor seems to regulate the abundance of dextrally coiled G. menardii specimens in the north-eastern Indian Ocean. Thus it is concluded that the coiling direction of G. menardii in 
the northeastern Indian Ocean has remained constant throughout most of the last $\sim 100,000 \mathrm{yr}$ BP with minor variations that are statistically insignificant. It shows that the coiling in G. menardii is heritable and not environmentally controlled, as also noted by Norris and Nishi (2001). Therefore, the variation in coiling direction of G. menardii cannot provide clues about late Quaternary paleoclimatic variations in the study area.

\section{Conclusions}

Based on the study of temporal changes in the abundance, size and coiling direction of planktic foraminiferal species G. menardii, from the northeastern Indian Ocean, we conclude that the abundance and size of G. menardii correlate with climatic changes during glacial-interglacial periods. Relatively increased abundance and larger size are observed during warm interglacial periods, whereas smaller and less number of G. menardii specimens is noted during the cold glacial periods. However, a better match between the abundance, size and oxygen isotopic composition of foraminifera indicates that the abundance and size of G. menardii is more affected by seawater temperature and salinity than productivity changes. The temporal changes in abundance and size of G. menardii vary from core-to-core, indicating the response to different physico-chemical conditions of the seawater at different locations. In comparison to abundance and size, the coiling direction of G. menardii does not show any systematic change during the time period covered by the core. The majority of the specimens are sinistrally coiled, which shows that late Quaternary climatic changes do not induce any change in coiling of $G$. menardii.

\section{Acknowledgement}

The authors are thankful to the Director, National Institute of Oceanography for permission to publish the findings. We are thankful to the anonymous reviewer for the suggestions that helped to improve the manuscript. The help of Miss Lea and Dr. Sujata Kurtarkar at various stages of this work is thankfully acknowledged. Prof. A. Mackensen and his staff at the Alfred Wegener Institute for Polar and Marine Research, Germany, are thankfully acknowledged for carrying out the isotopic analyses. Samples for this study were collected as part of the Ministry of Earth Sciences, Government of India funded, BENFAN project. 


\section{References}

Arnold, A.J., Kelly, D.C., Parker, W.C., 1995. Causality and Cope's Rule: Evidence from the planktonic foraminifera. J. Paleontol. 69, 203-210.

Balsam, W.L., Flessa, K.W., 1978. Patterns of planktic foraminiferal abundance and diversity in surface sediments of the western north Atlantic. Mar. Micropaleontol. 3, 279-294.

Bassinot, F.C., Labeyrie, L.D., Vincent, E.X.Q., Shackleton, N.J., Lancelot, Y., 1994. The astronomical theory of climate and the age of the Brunhes-Matuyama magnetic reversal. Earth Planet. Sci. Lett. 126, 91-108.

Bé, A.W.H., 1960. Ecology of Recent planktonic foraminifera: Part 2.-Bathymetric and seasonal distributions in the Sargasso Sea off Bermuda. Micropaleontology 6, 373-392.

Bé, A.W.H., Hutson, A., 1978. Ecology of planktonic foraminifera and biogeographic patterns of life and fossil assemblages in the Indian Ocean. Micropaleontology 23, 269-414.

Bé, A.W.H., Harrison, S.M., Lott, L., 1973. Orbulina universa d'Orbigny in the Indian Ocean. Micropaleontology 19, 150-192.

Bé, A.W.H., Tolderlund, D.S., 1971. Distribution and ecology of living planktonic foraminifera in surface waters of the Atlantic and Indian Ocean. In Micropaleontology of Oceans, (Edt. B.M. Funnel and W.R. Riedel), Cambridge University Press, Cambridge, pp. 105-149.

Bolli, H.M., 1950. The direction of coiling in the evolution of some Globorotaliidae. Contrib. Cushman Found. Foram. Res. 1, 82-89.

Bolli, H., 1951. Notes on the direction of coiling of rotalid Foraminifera. Contrib. Cushman Found. Foram. Res. 2, 139-143.

Bolli, H.M., 1971. The direction of coiling in planktonic foraminifera. In Micropaleontology of Oceans, (Edt. B.M. Funnel and W.R. Riedel), Cambridge University Press, Cambridge, pp. 639-648.

Cullen, J.L., Prell, W.L., 1984. Planktonic foraminifera of the northern Indian Ocean: Distribution and preservation in surface sediments. Mar. Micropaleontol. 9, 1-52.

Cushman, J. A., Harris, R.W., 1927. The significance of relative measurements in the study of foraminifera. Contrib. Cushman Found. Foram. Res. 2, 92-94.

Duplessy, J.C., 1982. Glacial to interglacial contrast in the northern Indian Ocean. Nature 295, 494498.

Ericson, D.B. and G. Wollin. 1956a. Micropaleontological and isotopic determinations of Pleistocene climates. Micropaleontology 2:257-270. 
Ericson, D.B., Wollin, G., 1956b. Correlation of six cores from the equatorial Atlantic and the Caribbean. Deep-Sea Res. 8, 104-125.

Ericson, D.B., Wollin, G., 1968. Pleistocene climates and chronology in deep-sea sediments. Science $162,1227-1234$.

Hecht, A.D., 1976a. Size variations in planktonic foraminifera: Implications for quantitative paleoclimatic. Science 192, 1330-1332.

Hecht, A.D., 1976b. An ecologic model for test size variation in recent planktonic foraminifera: application to the fossil record. J. Foramin. Res. 6, 295-311.

Hecht, A.D., Bé, A.W.H., Lott, L., 1976. Ecologic and paleoclimatic implications of morphologic variation of Orbulina universa in the Indian Ocean. Science 194, 422-424.

Huang, B., Cheng, X., Jian, Z., Wang, P., 2003. Response of upper ocean structure to the initiation of the North Hemisphere glaciation in the South China Sea. Palaeogeogra., Palaeoclimatol., Palaeoecol. 196, 305-318.

Huber, R., Meggers, H., Baumann, K.-H., Raymo, M.E., Henrich, R., 2000. Shell size variation of the planktonic foraminifer Neogloboquadrina pachyderma sin. in the Norwegian-Greenland Sea during the last 1.3 Myrs: Implications for paleoceanographic reconstructions. Palaeogeogra., Palaeoclimatol., Palaeoecol. 160, 193-212.

Kennett, J.P., Huddlestun, P., 1972. Late Pleistocene paleoclimatology, foraminiferal biostratigraphy and tephrochronology, western Gulf of Mexico. Quat. Res. 2, 3-9.

Knappertsbusch, M., 2007. Morphological variability of Globorotalia menardii (planktonic foraminifera) in two DSDP cores from the Caribbean Sea and the Eastern Equatorial Pacific. Carnets de Géologie / Notebooks on Geology 4, 1-34.

Madhupratap, M., Gauns, M., Ramaiah, N., PrasannaKumar, S., Muraleedharan, P.M., de Sousa, S.N., Sardessai, S., Muraleedharan, U., 2003. Biogeochemistry of the Bay of Bengal: Physical, chemical and primary productivity characteristics of the central and western Bay of Bengal during summer monsoon 2001. Deep-Sea Res. 50, 881-896.

Malmgren, B., Healy-Williams, N., 1978. Variation in test diameter of Orbulina universa in the paleoclimatology of the late Quaternary of the Gulf of Mexico. Palaeogeogra., Palaeoclimatol., Palaeoecol. 25, 235-240.

Malmgren, B. A., Kennett, J.P., 1976. Biometric analysis of phenotypic variation in Recent Globigerina bulloides d'Orbigny in the southern Indian Ocean. Mar. Micropaleontol. 1, 3-25, 1976. 
Malmgren, B., Kennett, J.P., 1978a. Test size variation in Globigerina bulloides in response to Quaternary palaeoceanographic changes. Nature 275, 123-124.

Malmgren, B., Kennett, J.P., 1978b. Late Quaternary paleoclimatic applications of mean size variations in Globigerina bulloides d'Orbigny in the southern Indian Ocean. J. Paleontol. 52, 1195-1207.

Malmgren, B.A., Kennett, J.P., 1981. Phyletic gradualism in a Late Cenozoic planktonic foraminiferal lineage; DSDP Site 284, southwest Pacific. Paleobiology 7, 230-240.

Martinson, D.G., Pisias, N.G., Hays, J.D., Imbrie, J., Moore, T.C., Shackleton, N.J., 1987. Age dating and the orbital theory of the ice ages: Development of a high-resolution 0 to 300,000year chronostratigraphy. Quat. Res. 27, 1-29.

Nagappa, Y., 1957. Direction of coiling in Globorotalia as an aid in correlation. Micropaleontology 3, 393-398.

Naidu, P.D., 1991. Glacial to interglacial contrasts in the calcium carbonate content and influence of Indus discharge in two eastern Arabian Sea cores. Palaeogeogra., Palaeoclimatol., Palaeoecol. $86,255-263$.

Naidu, P.D., Malmgren, B.A., 1995. Monsoon upwelling effects on test size of some planktonic foraminifera species from the Oman Margin, Arabian Sea. Paleoceanography 10, 117-122.

Narvekar, J., PrasannaKumar, S., 2006. Seasonal variability of the mixed layer in the central Bay of Bengal and associated changes in nutrients and chlorophyll. Deep-Sea Res. 53, 820-835.

Nigam, R., 1990. Paleoclimatic implications of size variation of Orbulina universa in a core from the north Indian Ocean. Curr. Sci. 59, 46-47.

Nigam, R., 1996. Potentiality of foraminifera in deciphering paleo-sea levels. In India's exclusive economic zone. (Eds.) Qasim, S.Z.; Roonwal, G.S., Omega Scientific Publishers; New Delhi; India, 225-232.

Norris, R.D., Nishi, H., 2001. Evolutionary trends in coiling of tropical Paleogene planktic foraminifera. Paleobiology 27, 327-347.

Parker, W.K., Jones, T.R., Brady, H.B., 1865. On the nomenclature of the Foraminifera; Pt. 10 (cont.) -The species enumerated by d'Orbigny in the "Annales des Sciences Naturelles. Annual Magazine of Natural History 16, 15-41.

PrasannaKumar, S., Muraleedharan, P.M., Prasad, T.G., Gauns, M., Ramaiah, N., de Souza, S. N., Sardesai, S., Madhupratap, M., 2002. Why is the Bay of Bengal less productive during summer monsoon compared to the Arabian Sea?. Geophys. Res. Lett. 29, 2235, doi:10.1029/2002GL016013. 
Regenberg, M., Nielsen, S.N., Kuhnt, W., Holbourn, A., Garbe-Schönberg, D., Andersen, N., 2010. Morphological, geochemical, and ecological differences of the extant menardiform planktonic foraminifera Globorotalia menardii and Globorotalia cultrata. Mar. Micropaleontol. 74, 96107.

Renaud, S., Schmidt, D.N., 2003. Habitat tracking as a response of the planktic foraminifer Globorotalia truncatulinoides to environmental fluctuations during the last $140 \mathrm{kyr}$. Mar. Micropaleontol. 49, 97-122.

Sarkar, A., Guha, A.K., 1997. Pleistocene paleoclimatic zonation in northern Indian Ocean as revealed from Globorotalia menardii abundance. Indian J. Mar. Sci. 26, 84-87.

Schmidt, D.N., Thierstein, H.R., Bollmann, J., 2004a. The evolutionary history of size variation of planktic foraminiferal assemblages in the Cenozoic. Palaeogeogra., Palaeoclimatol., Palaeoecol. 212, 159-180.

Schmidt, D.N., Renaud, S., Bollmann, J., Schiebel, R., Thierstein, H.R., 2004b. Size distribution of Holocene planktic foraminifer assemblages: biogeography, ecology and adaptation. Mar. Micropaleontol. 50, 319-338.

Schmidt, D.N., Thierstein, H.R., Bollmann, J., Schiebel, R., 2004c. Abiotic forcing of plankton evolution in the Cenozoic. Science 303, 207-210.

Schmidt, D.N., Lazarus, D., Young, J.R., Kucera, M., 2006. Biogeography and evolution of body size in marine plankton. Earth-Sci. Rev. 78, 239-266.

Schott, W., 1935. Die Foraminiferen in dem aequatorialen Teil des Atlantischen Ozeans. Deutsch. Atlant. Exped. "Meteor" 1925-1927, Wiss. Ergebn. 3, 43-134.

Schott, F.A., McCreary, J.P. Jr., 2001. The monsoon circulation of the Indian Ocean. Progr. Oceanogra. 51, 1-123.

Shankar, D., Vinayachandran, P.N., Unnikrishnan, A.S., 2002. The monsoon currents in the north Indian Ocean. Progr. Oceanogra. 52, 63-120.

Sierro, F.J., 1985. The replacement of the "Globorotalia menardii" group by the Globorotalia miotumida group: An aid to recognizing the Tortonian/Messinian boundary in the Mediterranean and adjacent Atlantic. Mar. Micropaleontol. 9, 525-535.

Sierro, F.J., Flores, J.A., Civis, J., Gonzailez Delagado, J.A., Frances, G., 1993. Late Miocene globorotalid event-stratigraphy and biogeography in the NE- Atlantic and Mediterranean. Mar. Micropaleontol. 21, 143-168. 
Somayajulu, Y.K., Murty, V.S.N., Sarma, Y.V.B. 2003. Seasonal and inter-annual variability of surface circulation in the Bay of Bengal from TOPEX/Poseidon altimetry. Deep-Sea Res. 50, 867-880.

Thiede, J., 1971. Variations in coiling ratios of Holocene planktonic foraminifera. Deep-Sea Res. 18, 823-831.

Unger, D., Ittekkot, V., Schafer, P., Tiemann, J., Reschke, S., 2003. Seasonality and interannual variability of particle fluxes to the deep Bay of Bengal: influence of riverine input and oceanographic processes. Deep-Sea Res. 50, 897-923.

Vinayachandran, P.N., Shetye, S.R., 1991. The warm pool in the Indian Ocean. Proceed. Ind. Acad. Sci. (Earth Planet Sci.) 100, 165-175.

Weninger, B. and Jöris, U.O., 2006. Danzeglocke Cologne Radiocarbon Calibration and Palaeoclimate Research Package, (http://www.calpal-online.de/).

Williams, N.H., 1984. Quantitative image analysis: Application to planktonic foraminiferal paleoecology and evolution. Geobios 8, 425-432.

Williams, N.H., 1989. Morphological changes in living foraminifera and the thermal structure of the water column, western North Atlantic. Palaios 4, 590-597. 


\section{Legend to Figures and Table:}

Figure 1: Location of the cores collected along a transect in the north-eastern Indian Ocean.

Figure 2: The maximum size of the G. menardii specimens was measured in spiral view using a computer attached to the microscope.

Figure 3: Relationship between depth and age of the three cores. The lower panel shows the oxygen isotopic changes which are used to extend the chronology beyond AMS dates.

Figure 4: Temporal variation in abundance of G. menardii in cores SK 157/20 (A), SK 157/12 (B) and CC1GC2 (C). The faint symbols and line are the actual values while the dark line is the 5 point running average. Alternate grey and white bands represent marine isotopic stages.

Figure 5: Down-core variation in average size of G. menardii in cores SK 157/20 (A), SK 157/12 (B) and CC1GC2 (C). The faint symbols and line are the actual values while the dark line is the 5 point running average. Alternate grey and white bands represent marine isotopic stages.

Figure 6: Temporal variation in percentage of dextrally coiled specimens of G. menardii in cores SK 157/20 (A), SK 157/12 (B) and CC1GC2 (C). Alternate grey and white bands represent marine isotopic stages.

Figure 7: Correlation between G. menardii abundance and oxygen and carbon isotopic ratios in all the cores.

Figure 8: Correlation between G. menardii size and oxygen and carbon isotopic ratios in all the cores.

Table 1: Details of the cores.

Table 2: Details of the Accelerator Mass Spectrometer radiocarbon dates obtained for selected samples from the three cores.

Plate 1: Scanning electron micrographs of three common Globorotalid species. 1. Umbilical, 2. Spiral, and 3. Apertural view of Globorotalia cultrata (d'Orbigny, 1839); 4. Umbilical, 5. Spiral, and 6. Apertural view of Globorotalia menardii (Parker, Jones and Brady, 1865); 7. Umbilical, 8. Spiral, and 9. Apertural view of Globorotalia tumida. 
Table 1

\begin{tabular}{|l|l|l|l|l|l|l|}
\hline Core & Latitude & Longitude & $\begin{array}{l}\text { Water Depth } \\
(\mathbf{m})\end{array}$ & $\begin{array}{r}\text { No. of } \\
\text { Samples }\end{array}$ & $\begin{array}{l}\text { Sea } \\
\text { Temperature }\left({ }^{\circ} \mathbf{C}\right)\end{array}$ & $\begin{array}{l}\text { Sea Surface } \\
\text { Salinity }\end{array}$ \\
\hline SK 157/20 & $12.13^{\circ} \mathrm{N}$ & $88.70^{\circ} \mathrm{E}$ & 3202 & 55 & 28.64 & 33.43 \\
\hline SK 157/12 & $04.40^{\circ} \mathrm{N}$ & $85.38^{\circ} \mathrm{E}$ & 3439 & 50 & 28.39 & 34.31 \\
\hline $\mathrm{CC} 1 \mathrm{GC} 2$ & $04.57^{\circ} \mathrm{S}$ & $82.58^{\circ} \mathrm{E}$ & 3700 & 74 & 28.39 & 34.63 \\
\hline
\end{tabular}

Table 2

\begin{tabular}{|l|l|l|}
\hline Sample Description & AMS Radiocarbon Age (Yrs) & Calibrated age range (yr BP) \\
\hline SK 157/20 20-22 & $6510 \pm 35$ & $7031 \pm 85$ \\
\hline SK 157/12 02-04 & $3700 \pm 25$ & $3526 \pm 35$ \\
\hline SK 157/12 48-50 & $22170 \pm 130$ & $26343 \pm 518$ \\
\hline CC1 GC2 00-02 & $9500 \pm 45$ & $10270 \pm 40$ \\
\hline CC1 GC2 49-50 & $>50560$ & Beyond Calibration Range \\
\hline
\end{tabular}




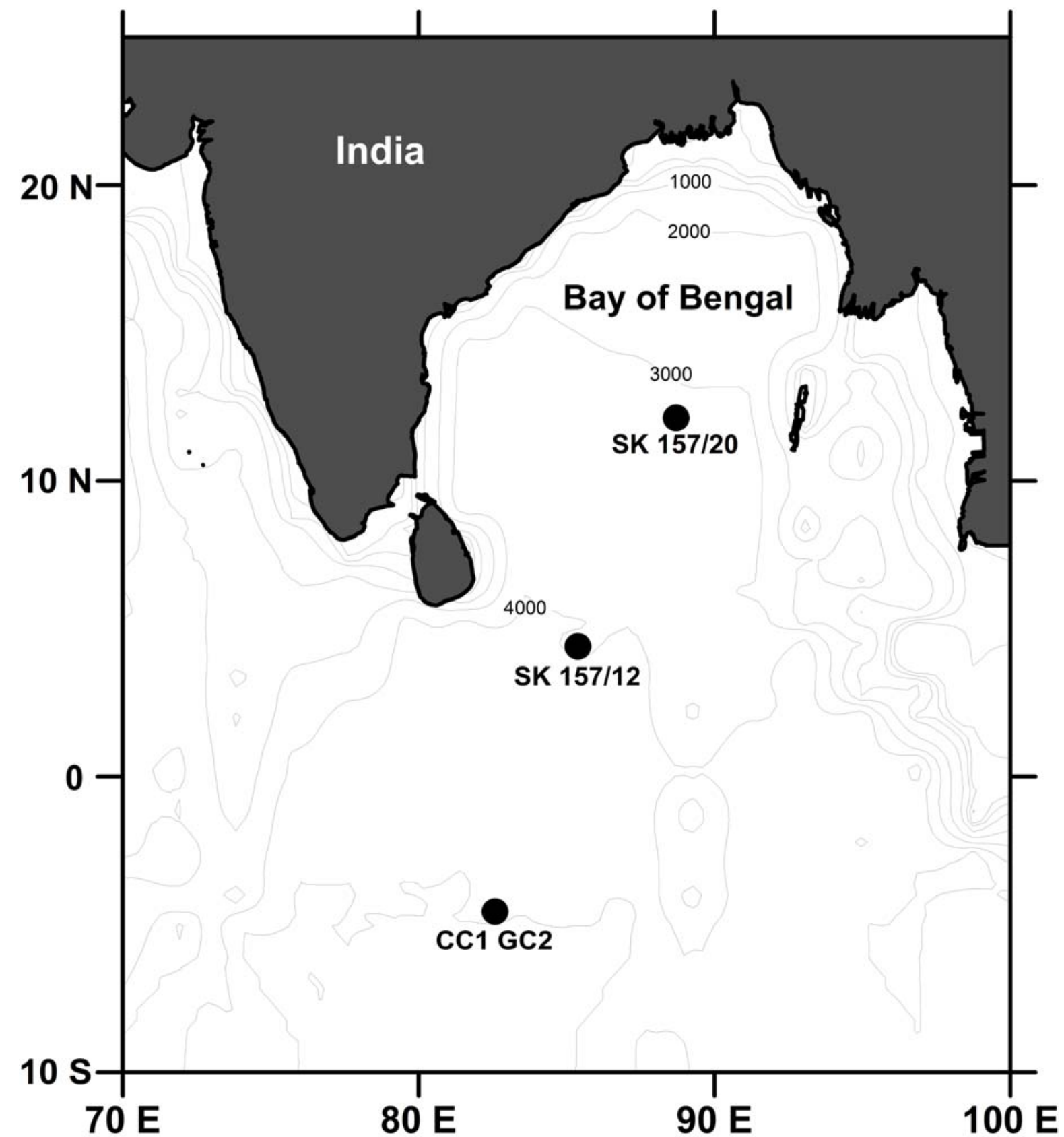

Figure 1 


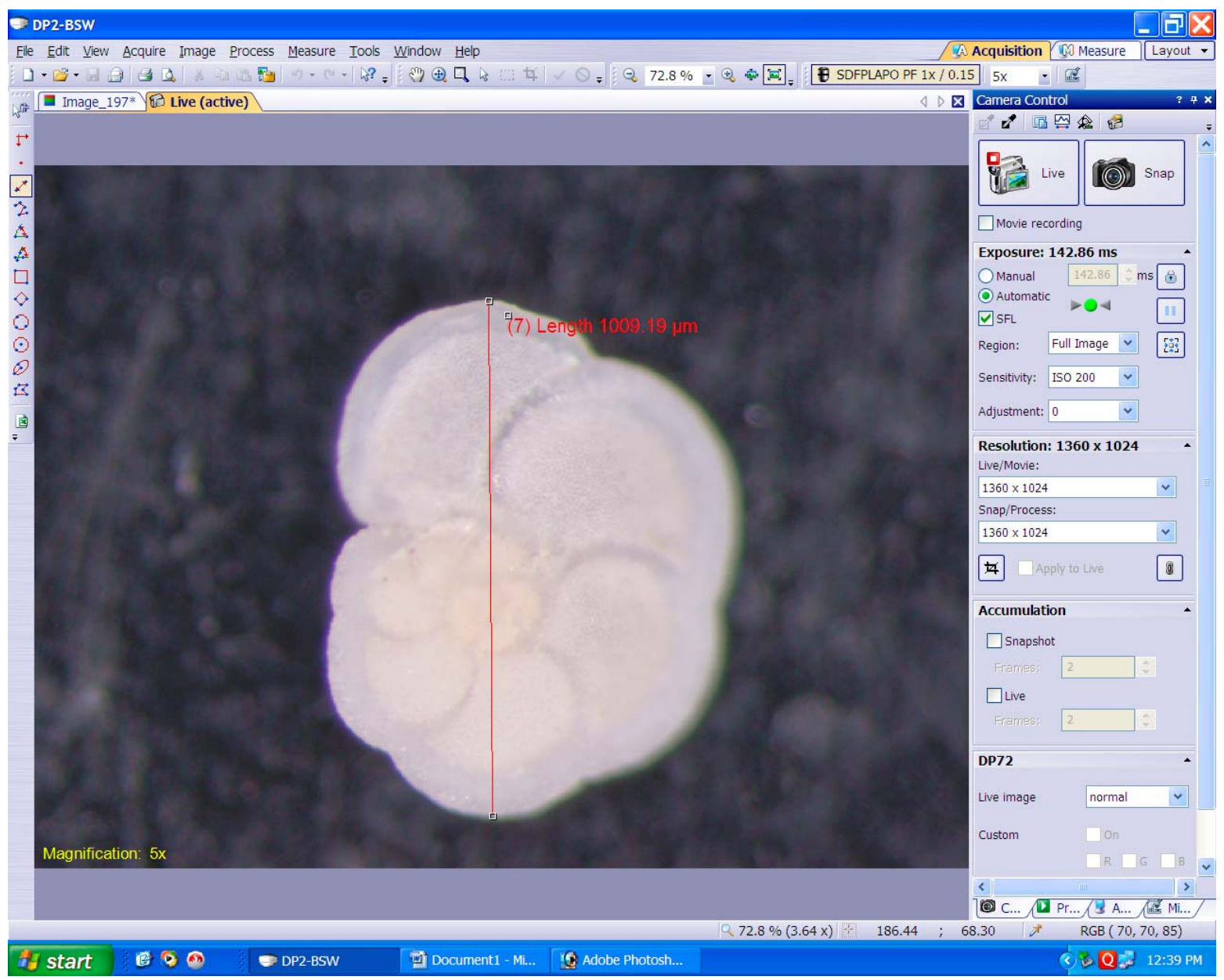

Figure 2 


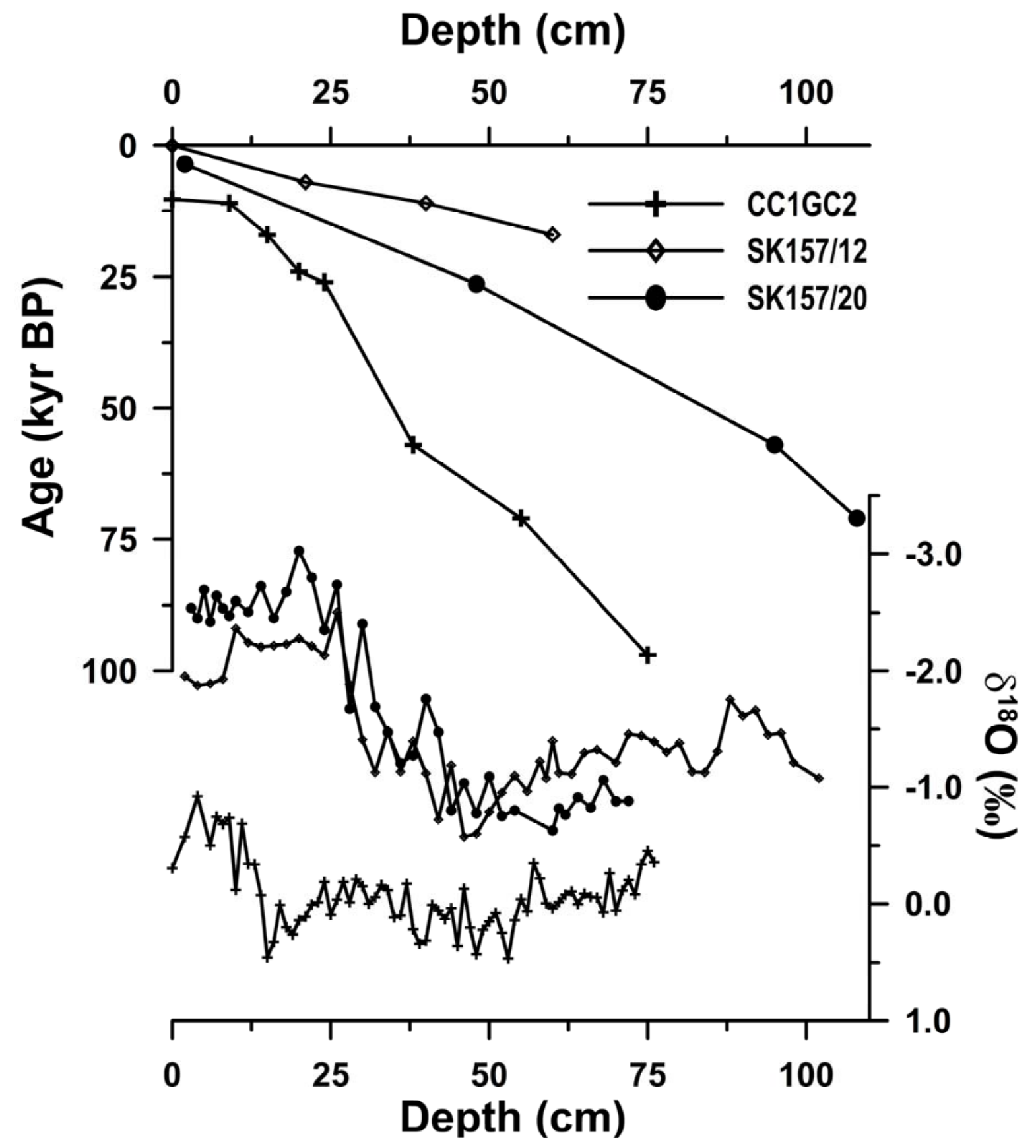

Figure 3 


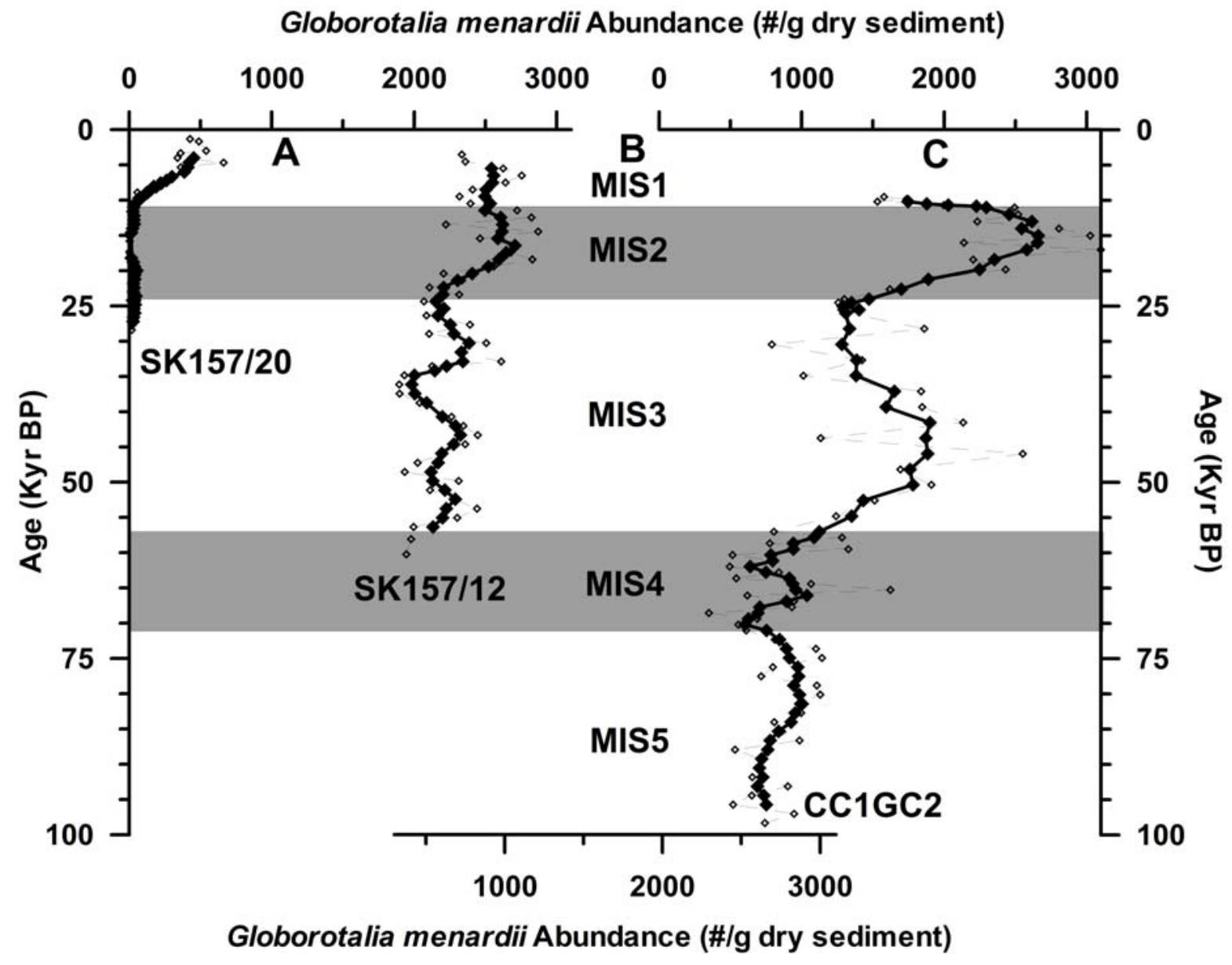

Figure 4 


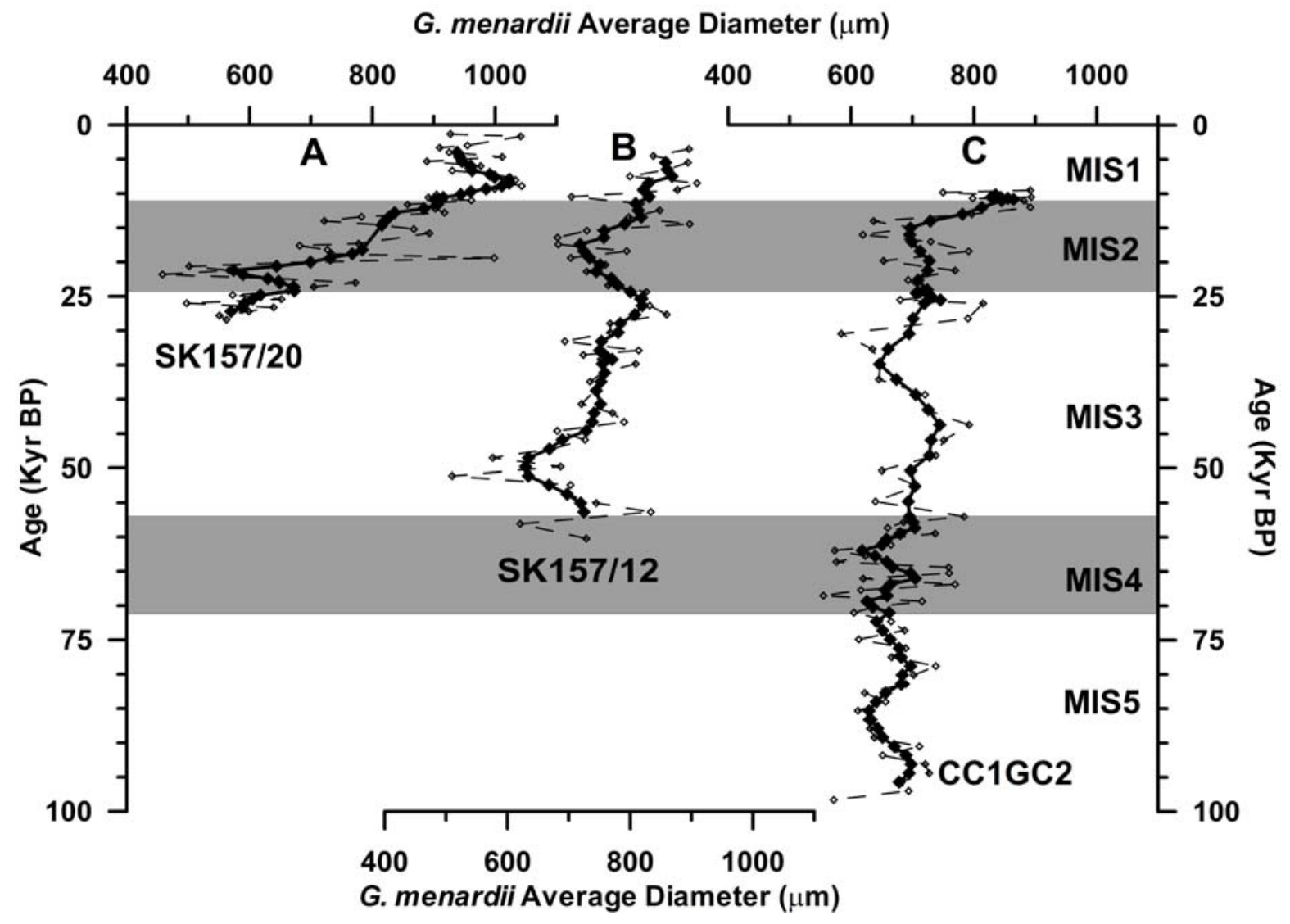

Figure 5 


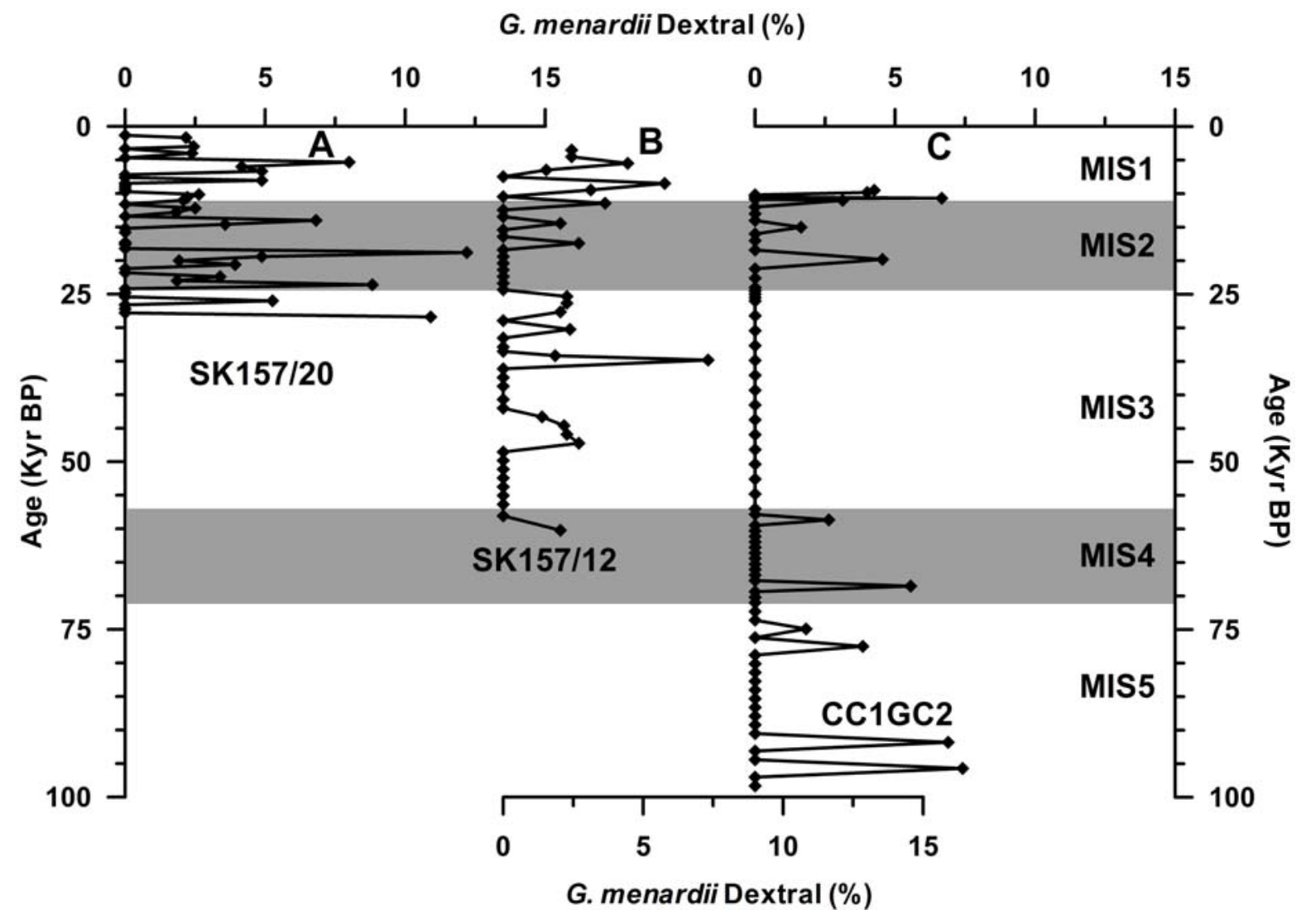

Figure 6 

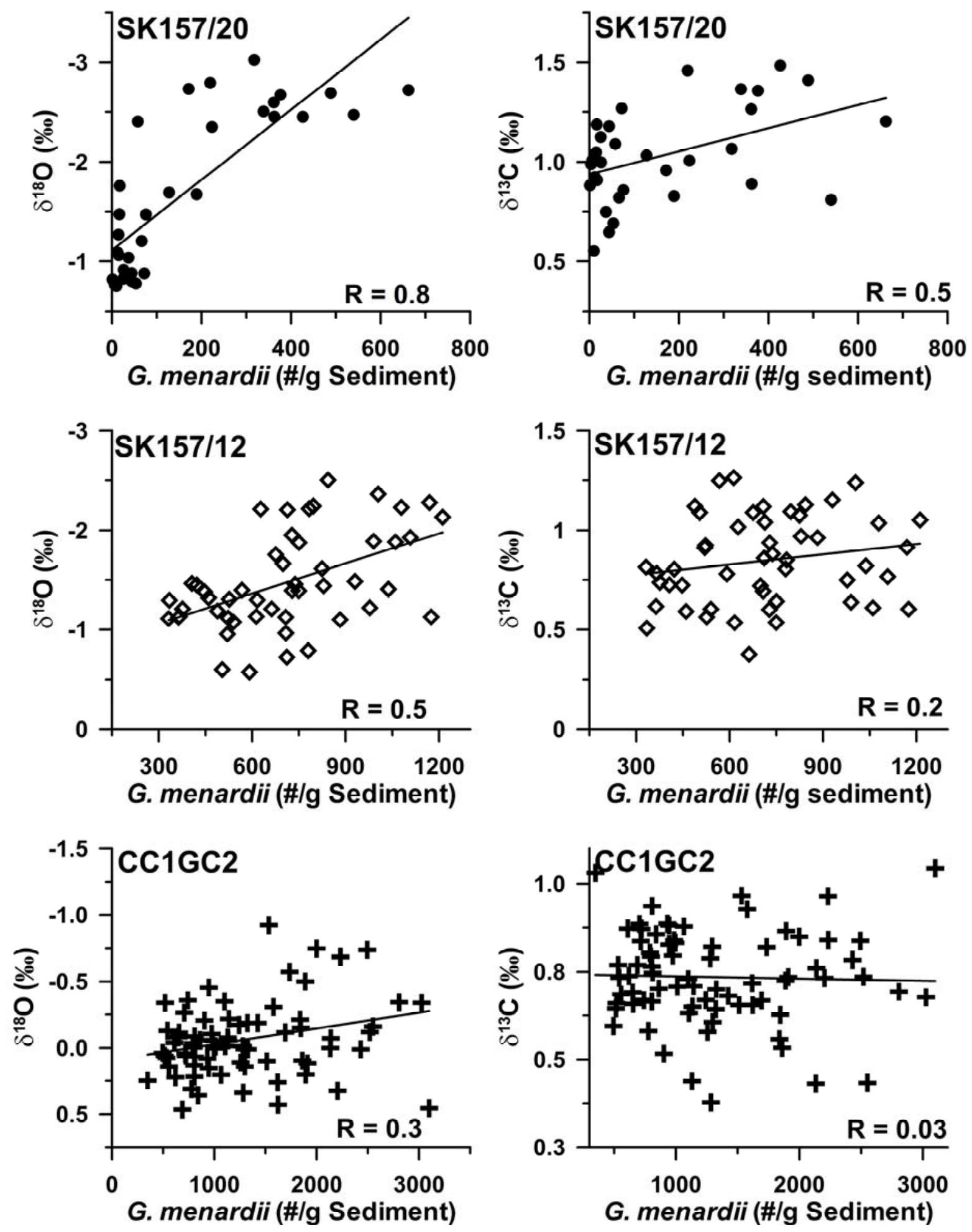

Figure 7 

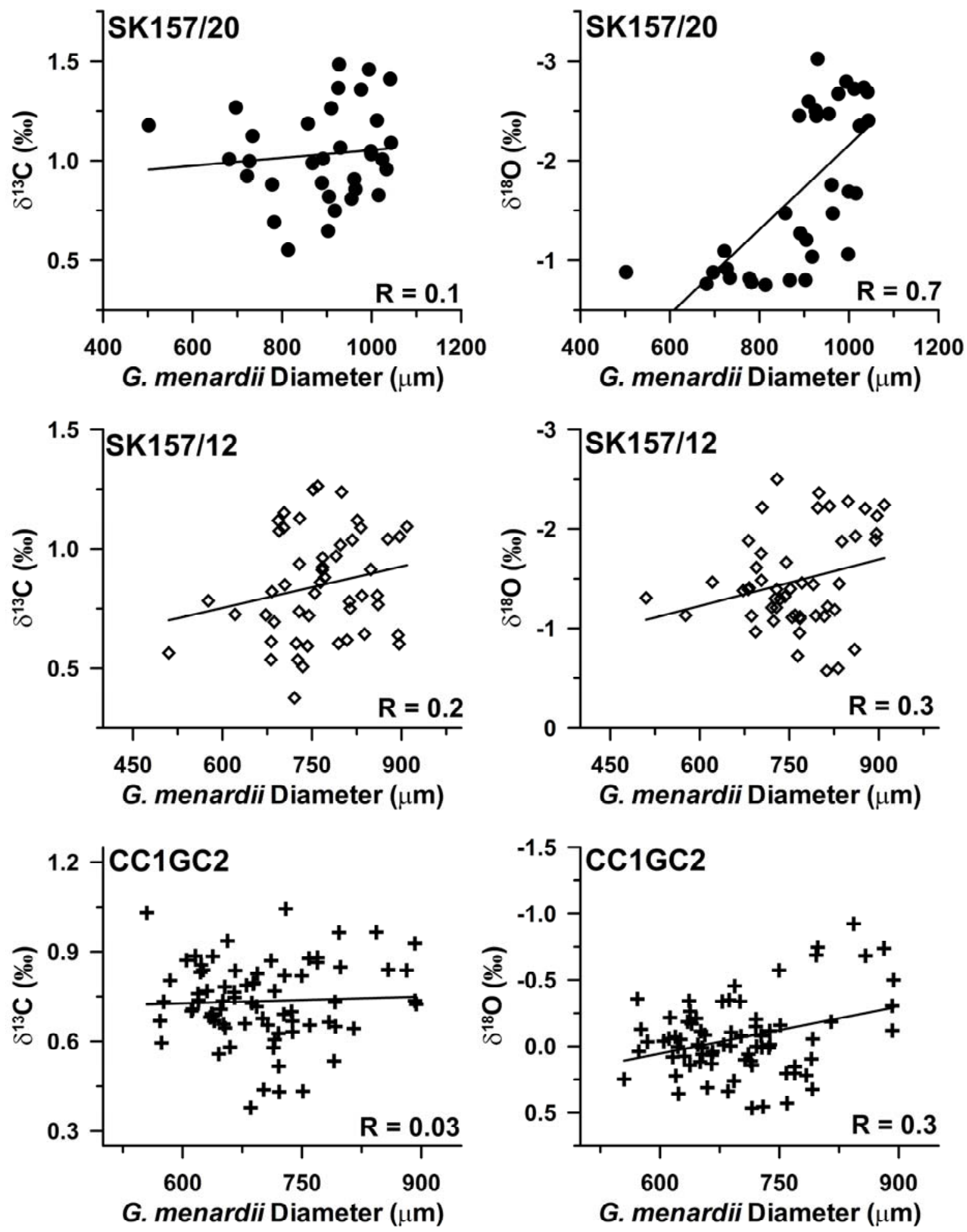

Figure 8 


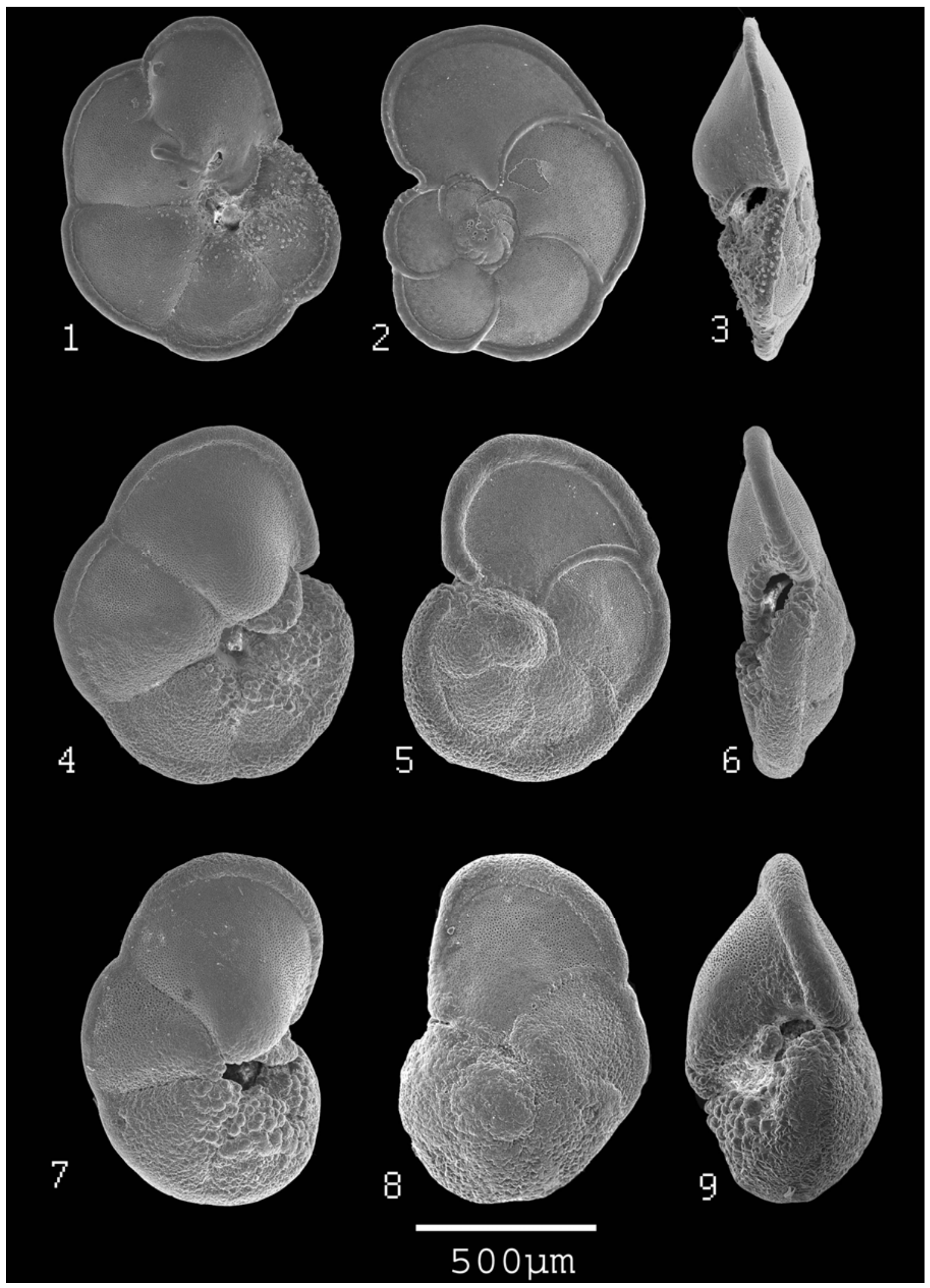

Plate 1 